\section{Interview met Alex Van Wynsberghe}

Rik De Coninck, Amsab-ISG

Uit welk milieu kom je en hoe ben je op je zeventiende in 1967 in de Papierfabriek van Langerbrugge beginnen werken?

Ik kom uit een vissersfamilie in Boekhoute. Bij het afsluiten van de Braakman (een arm van de Schelde) in 1952 stond mijn moeder erop dat mijn vader werk zou zoeken in de fabriek. Enkele familieleden zijn visser gebleven en varen nu nog met een BOU-nummer, maar mijn vader heeft dus ander werk gezocht. Ik heb een diploma A3 elektriciteit behaald en hoopte zo als elektricien werk te vinden, maar uiteindelijk is dat niet gelukt, ook niet in de papierfabriek. Ik heb dus altijd papier gemaakt aan de machine, aan de PM 2, dus aan papiermachine 2. Ik was nog geen achttien toen ik er begon te werken in het vierploegenstelsel en dat was eigenlijk niet toegestaan omdat ik te jong was.

De Papierfabriek was toen in volle evolutie.

Tot 1964 was de Papierfabriek van Langerbrugge een Belgische fabriek van de Société Générale. Toen kwam er een akkoord tussen de Société en het Duitse Feldmühle A.G. waarbij elk $30 \%$ van de aandelen kreeg - de overige $40 \%$ was in handen van kleine aandeelhouders - en de Société zich enkel bekommerde om de financiën terwijl het beheer van de fabriek overgelaten werd aan Feldmühle. Ik herinner me nog dat de fabriek enkele arbeiderswoningen bezat op het eilandje waarop ze gebouwd is. Die woningen werden verhuurd aan personeel met problemen en de syndicale delegatie had inspraak in de toewijzing van deze woningen. In 1969 werden ze verkocht.

Dat was maar een van de veranderingen die het gevolg waren van de participatie van Feldmühle A.G.?

Net voor ik er begon te werken, had de directie de productie gereorganiseerd. Er werd in 1966 gestart met een non-stopproductie - met 10 revisiestops op de feestdagen - en een vierploegenstelsel. De directie kon dit maar gedaan krijgen door een gulle cao te ondertekenen in 1966. Deze basis-cao voorzag in talrijke voordelen zoals onder meer een productiepremie, die een toeslag van ten minste $6 \%$ en maximaa $6 \%$ bovenop het loon kon betekenen, en hoge ploegenpremies met $6 \%$ toeslag voor de ochtend- en middagploeg en $12 \%$ voor de nachtploeg. Voor werk op zondag (van zaterdag $22 \mathrm{u}$ tot maandag $6 \mathrm{u}$ ) kregen de arbeiders dan nog eens dubbel loon en ploegvergoedingen. We verkregen ook de afschaffing van de carensdag, ja toen al, en de 40 urenwerkweek, doordat we twee uur per week compensatie kregen.

Kort daarop volgde een economische crisis en toch werden er nieuwe sociale voordele gehaald?

In 1978 was er een korte staking, ik herinner me dat er niemand kwam opdagen aan de fabriekspoort en dat de piketten zich verveelden; toen werden de lonen en de ploegenpremies gevoelig aangepast en werd een eindejaarspremie van één twaalfde op het jaarloon verworven.

Maar in 1984 kwam er een grote investering met kapitaalsverhoging en de overname van alle aandelen door Feldmühle. We werden gedwongen om de cao te herzien en ee nieuwe vijfploegen-cao werd goedgekeurd. Dit hield onder meer in dat een aantal premies zoals de dubbele ploegenpremies en de compensatiedagen, die de directie wou vervangen door een loonforfait, en niet meer werden toegekend aan de nieuw aangeworvenen. Voor de werknemers die wel al in dienst waren, werd die forfa niet geïndexeerd. Op die manier werden de oorspronkelijke voordelen die we gekregen hadden bij de invoering van de non-stopproductie, gereduceerd. Vele jaren bleef er een gespannen sfeer tussen nieuwe en oud werknemers! Bovendien werd het vijfploegenstelsel ingevoerd.

De cao over de vijf ploegen heeft de toenmalige delegatie van het ABVV niet bepaald populair gemaakt, en vooral het terug overschakelen in de zomer naar vier ploegen blijft tot op de dag van vandaag voor discussie zorgen. Het zit zo: het normaal lopende vijfploegensysteem kan enkel bij een gemiddelde arbeidstijd van 33,6 uren per week. Maar om een gemiddelde van 36 ure te halen op jaarbasis werd er in de zomer gedurende twee maanden overgeschakeld naar een vierploegensysteem met 42 uren per week.

Ondertussen was je al volop actief in de vak bond. Hoe kwam je in de syndicale delegatie?

Toen ik 21 was ben ik actief geworden, zowel in de BSP in Boekhoute als in de vakbond in het bedrijf. Maar voor de sociale verkiezingen van 1971 was het te laat. Bij de volgende verkiezingen in 1975 stond wel op de lijst en werd ik verkozen voor de ondernemingsraad.
Enige tijd later werden de vrijdag- en maandagstakingen tegen de inleveringstreinen van de regering-Martens $\mathrm{V}$ en VI opgezet en onze effectieven wilden niet meestaken zodat alleen de militanten piket stonden. Dat gaf aanleiding tot zware discussies to in het bestuur van de Algemene Centrale (AC). Uiteindelijk trad de oude delegatie af en zo werd ik syndicaal afgevaardigde, eerst nog een jaar met Freddy Bruwière, later met Alex Goethals die ook van Boekhoute is.

We waren echte vrienden, een tandem die samen aan één zeel trok en ijverde voor een strijdbare militantenkern. Bij de eerstvol-

gende sociale verkiezingen in 1991 behaalden we drie zetels en in 1995 kregen we de volstrekte meerderheid met vier zetels.

We waren strijdbaar, goed opgeleid, mondig en hadden een gedegen dossierkennis.

Ik volgde vanaf 1975 alle opleidingen van de $A C$ en ook de interprofessionele opleidingen van het ABVV. Later werden Alex Goethals en ikzelf animatoren van die vormingen en ontmoetten we talloze jonge militanten van diverse sectoren. We waren graag geziene gasten op militantenconcentraties, betogingen, piketten en congressen. Ik heb ook nog gesolliciteerd om vakbondssecretaris te worden maar uiteindelijk was het Alain Clauwaert die de job kreeg, terecht trouwens.

Nu even terug naar de vakbondswerking in de fabriek. De situatie daar veranderde snel na de overname door Stora die zware herstructureringen oplegde.

Rond 1990 had de Zweedse papierreus Stora de fabriek overgenomen. Deze overname

liet haar sporen na via drie opeenvolgende herstructureringen. Ik meen dat een eerste 
herstructurering doorgevoerd werd in 1991 of 1992, er waren toen nog een 920 werknemers, en die herstructurering leidde tot ongeveer 200 afvloeiingen, hoofdzakelijk via brugpensioenen, stopzetten van tijdelijke contracten en alternerend leren. Een klein aantal arbeiders werd effectief afgedankt. Het was een eerste mokerslag.

Drie jaar later volgde de tweede fase. Men zou papiermachine 1 uit productie nemen met opnieuw een verlies van 120 arbeidsplaatsen, de helft ervan waren naakte ontslagen. Onder de arbeiders waren enkele militanten; ze werden ontslagen na een akkoord in het paritair comité

Nog een goed jaar later wou de nieuwe directeur papiermachine 1 terug opstarten, maar dan zonder personeelsuitbreiding. We kregen toen zelfs de 35 urenwerkweek. Zes maand later - dat was in 1997 en er waren nog een 580 werknemers - kregen we een nieuwe directeur, die zag de zeer slechte resultaten van papiermachine 1 en van de hele fabriek en na een doorlichting van Mc Kinsey werd een nieuw herstructureringsplan opgemaakt met de definitieve 'sluiting' van papiermachine 1 en een aanta andere afdelingen. Die herstructurerin leidde tot het verlies van nog eens 189 arbeidsplaatsen, 175 arbeiders en 14 bedienden. Deze afvloeiingen konden slechts heel miniem opgevangen worden door het stelsel van brugpensioen, dus er dreigden veel naakte ontslagen en drama's.

Om de schade en de naakte ontslagen te beperken, hadden we een arbeidsduurvermindering gevraagd met het plan-Van de Lannotte, tot 33,6 uren met loonverlies maar de directie vroeg 38 uur voor

hetzelfde loon. Uiteindelijk werd een cao

afgesloten met enerzijds een vermindering van 189 arbeidsplaatsen en anderzijds een verhoging van de arbeidstijd met één uur tot 36 uur. De productiepremie werd om besparingsredenen (sociale lasten) omgezet in een pensioenspaarplan en een hospitalisatieverzekering.

Er was ook een zware aanval op de vakbondskern.

De directie had het nooit goed begrepen op de syndicale delegatie en zeker niet op de ABVV-delegatie; daarom had ze voor deze operatie de hulp van een advocatenbureau ingeroepen om zich zo op een goedkope manier van een groep lastige délégués te ontdoen, en ze vroeg de opheffing van de bescherming van elf syndicalisten. De discussies laaiden hoog op en in de delegaties ontstonden twee partijen. De verschillen i syndicale visie en strategie zouden definitief een einde maken aan mijn vriendschap met Alex Goethals.

In het paritair comité werd geen akkoord bereikt over het ontslag van de elf beschermden omdat de directie een procedure van ontslag om dwingende redenen tegen mij en Dirk Van Rijkeghem (ACV) had opgestart. De directie vroeg ons ontslag om 'dwingende redenen', wegens een artikel in de krant over de lopende herstructurerings-cao. De arbeidsrechtbank besliste in kortgeding dat de ontslagen nie gerechtvaardigd waren. Daarop besliste de directie om hen toch maar af te danken om 'herstructureringsredenen'.

We vochten dit ontslag aan, de advocaten van het ABVV en het ACV kregen gelijk, maar wederopname is nog steeds geen verplichte regel. Acht jaar procederen voor slechts vijf van hen, voor twee zelfs tot in
Cassatie, gaf ons gelijk. Wat het ACV en het ACLVB voor de anderen hebben gedaan, is me niet bekend. Voor alle vier de ABVV'ers werd geprocedeerd en ze kregen allen gelijk.

Je volgde ook de werking van het Comité voor Veiligheid en Gezondheid?

Op het gebied van veiligheid en milieu werden er na enkele grote branden en een drietal dodelijke ongevallen grote inspanninge geleverd om de veiligheid in de fabriek te verbeteren, vooral op het vlak van afschermen van draaiende onderdelen, brandvoorkoming, orde en netheid, het beter doseren van chemicaliën en geluidsoverlast. Door een nieuwe technologie werd de geluidshinder gevoelig verminderd van $120 \mathrm{dBA}$. tot 95dBA. Dit had ook milieugevolgen en de economische impact van deze ingreep was een stimulans om grote inspanningen te leveren op het vlak van vermindering en hergebruik van grondstoffen. Er volgden nog een resem andere veranderingen in het productieprocédé. Zo gebruikte men oorspronkelijk cellulosevezels, dat is chemisch ontvezeld hout, als grondstof, maar die werden geleidelijk vervangen door oud papier en thermisch-mechanische pulp, dus het verwerkt afvalhout uit de zagerijen. Op het einde van de jaren 70 werd met veel staatssteun een waterzuivering gebouwd en kwam een einde aan de vervuilende lozingen in het kanaal. De boomschors werd verkocht om te composteren. Afvalsli door het ontinkten van oud papier werd afgevoerd naar een klasse 1- stort. De thermisch-mechanische pulpprocedure had ook als voordeel eigen stoom op te wekken, zo kon een deel van de energieverslindende slijperij worden stilgelegd en samen met de bouw van een warmteherwinning werd veel bespaard op de elektriciteitsfactuur. Na 1985 werd de oude, in onbruik geraakte kanaalarm gedempt met de bedoeling er nieuwe machines op te bouwen. Door de Gentse haven werd een laadkaai aangelegd zodat het transport van papier en grondstoffen per schip mogelijk werd.

Het zou evenwel nog tot na de grote

herstructurering van 1997 duren vooraleer deze plannen uitgevoerd werden. Vandaag worden op twee machines, de PM 3 en PM 4 , nog twee soorten papier geproduceerd, voor dagbladen en magazines, die voor $100 \%$ uit oude papiervezels bestaan. Het risicoafval wordt niet langer gestort maar verbrand in een eigen verbrandingsinstallatie met een centrale voor eigen stoom en elektriciteitsproductie. Om volledig onafhankelijk te worden van energieleveranciers werkt men anno 2007 volop aan de plannen voor een nieuwe eigen elektriciteitscentrale.

De eerste twee papiermachines zijn er niet meer. De eerste was in productie van 1932 tot zij in 1998 stilgelegd werd en bijna volledig werd verschroot. De tweede werd nog volledig herbouwd in 1986, maar werd verkocht in 1998 en staat nu ergens in Pakistan. De derde was gebouwd in 1957 voor de productie van dagbladpapier en werd na 1998 omgebouwd voor magazinepapier met een breedte van $6,90 \mathrm{~m}$ en haalt thans op met een snelheid van ongeveer $1200 \mathrm{~m} / \mathrm{min}$ De vierde machine produceert dagbladpapier van $9 \mathrm{~m}$ breedte aan een snelheid van bijna $2000 \mathrm{~m} / \mathrm{min}$. 
Negen jaar na de grote herstructurering, in 2006 dus, werden ook Alex Goethals en Tony Neyt na een heftige staking, zonder vorm van proces en zonder betaling van de beschermvergoeding aan de kant gezet. Het bewijst dat bedrijven die over voldoende middelen beschikken zich zonder problemen van moeilijke delegaties kunnen ontdoen en dat de wet nog steeds geen afdoende bescherming biedt. Te bedenken dat deze middelen afkomstig kunnen zijn van subsidies van de staat, onze eigen belastingen dus!

Mijn besluit is: waar eens de Papierfabriek van Langerbrugge de toon heeft gezet in de sociale strijd om en in de Kanaalzone, rest er nu nog een internationale kapitaalreus, die bepaalt hoe je syndicaal mag (mee)denken.

Ik wil nu nog enkele mensen bedanken voor hun jarenlange steun, begrip en vriend-

schap: Wilfried Hoste, Luc De Wilde, Martin Lambrecht en Rik De Kezel.

Uw sociaal engagement was niet beperkt tot aan de fabriekspoort?

Tijdens de Apartheid in Zuid-Afrika, kregen we ooit bestellingen voor dit land, ik vroeg toen in de ondernemingsraad te onderzoeken of ons product gebruikt werd voor de ondersteuning van het regime en zo ja, om dergelijke bestellingen te weigeren. Zo kaartte ik ook het probleem van Shell aan en vroeg geen olie af te nemen zolang zij het regime ginder steunden.

Samen met mijn echtgenote - Gerda De Letter, van wie ik thans gescheiden leef - heb ik me steeds om de zwakkeren in de maatschappij bekommerd; zo stimuleerden en werkten we mee aan de 11.11.11-acties in onze gemeente.

In 1988 gingen we met 'ABVV'ers voor Nicaragua' op werkbrigade en zouden er voor de landarbeidersbond ATC een basisschool gaan bouwen. Twee jaar later gingen we terug om boompjes te planten en een loods op te trekken. Hiervan bestaan twee videoreportages van ongeveer een half uur. In 1993 ging ik terug om de vakbondslokalen te schilderen en een uitgebreid bezoek aan het land en zijn inwoners te brengen. In

België koppelden we alles terug met info- en gespreksavonden. Prefinanciering haalden we uit een benefiet en andere acties. In 1992 ontvingen we zelf een delegatie van ATC'ers.

Van zodra de grens met het Oostblok open kwam trokken we met 'Adoptie Dorpen Roemenië' regelmatig met hulpgoederen naar deze regio. Thans is Roemenië mijn tweede vaderland.

Daarnaast was ik politiek actief in de Socialistische Partij sinds 1971 en zetelde van 1994 tot 2000 in de gemeenteraad van Assenede. Momenteel ben ik voorzitter van de Cultuurraad Assenede.

\section{Archief van Bert Van Hoorick \\ Martijn Vandenbroucke, Amsab-IS}

Bert Van Hoorick was ongetwijfeld een van de markantste figuren van het naoorlogse politieke leven in het Aalsterse. Hij was lange tijd volksvertegenwoordiger (tussen 1944 en 1949 voor de Kommunistische Partij van België, tussen 1957 en 1976 voor de Belgische Socialistische Partij) en speelde een belangrijke rol in de lokale politiek van Aalst, waaronder twaalf jaar als schepen van Onderwijs en Cultuur. (1)

Het archief van Van Hoorick raakte helaas verspreid: een deel ervan kwam terecht in het Aalsterse stadsarchief, een ander deel werd reeds voor zijn dood overgedragen aan het toenmalige AMSAB (1994), een laatste deel werd na zijn overlijden door zijn weduwe eveneens aan Amsab-ISG geschonken (2000). Naar aanleiding van de nadere ontsluiting van dit laatste archiefdeel, werd besloten de bestaande stortingslijst uit 1997, opgemaakt door archivaris Rik Hemmerijckx, te herwerken. Op die manier krijgt de onderzoeker een volledig zicht op het deel dat hier bewaard wordt. Weinig stukken dateren van voor 1957, al zitten in de latere schenking wel enkele dossiers met gegevens over het verzet en de oorlogsjare en een aantal interessante bundels briefwisseling uit de laatste decennia van zijn leven. Toch bevat het archief vooral materiaal met betrekking tot zijn persoonlijk leven en zijn politieke inzet in het Aalsterse. Over zijn werkzaamheden in het parlement is niets te vinden.

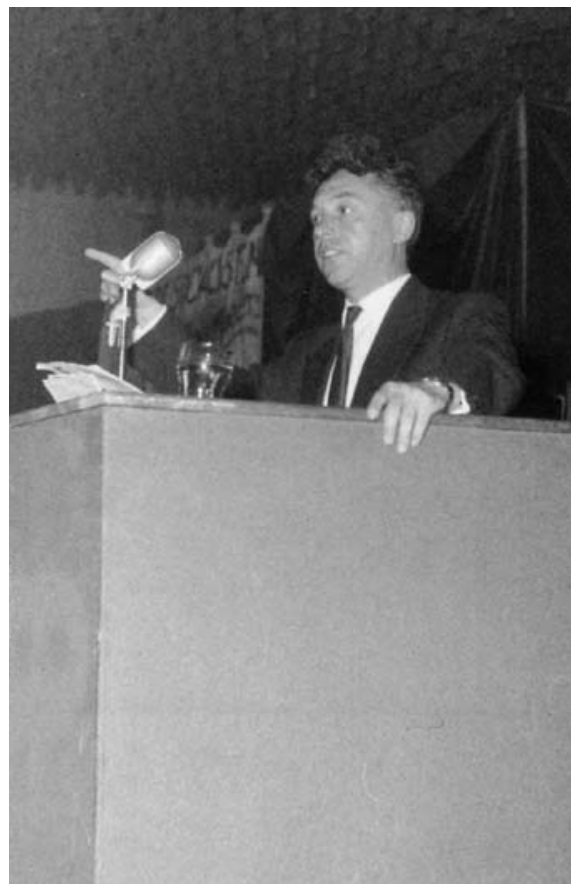

Bert Van Hoorick, jaren 50

Het archief bevat 124 stukken, opgeborgen in 13 archiefdozen (1,4 lopende meter) en bestrijkt de periode 1935-2000. Het is consulteerbaar mits toestemming van de dienstdoende archivaris, met uitzondering van enkele dossiers recente briefwisseling.

(1) Voor meer biografische gegevens over Van Hoorick, zie: R. HEMMERJCKX, Het archief van Bert 